\title{
Energy and protein requirements of crossbred Holstein $x$ Zebu steers fed different levels of calcium and phosphorus in the diet
}

\author{
Exigências de energia e proteína de bovinos castrados mestiços \\ Holandês $\mathrm{x}$ Zebu alimentados com diferentes níveis de cálcio e \\ fósforo na dieta
}

\author{
Diego Zanetti ${ }^{*}$; Sebastião de Campos Valadares Filho ${ }^{2}$; Edenio Detmann ${ }^{2}$; \\ Marcos Vinicius Carneiro Pacheco ${ }^{3}$; Letícia Artuzo Godoi ${ }^{3}$; Breno de Castro Silva ${ }^{3}$; \\ Stefanie Alvarenga Santos"; Lays Débora Silva Mariz; Mário Fonseca Paulino²; \\ Jarbas Miguel da Silva Júnior ${ }^{1}$
}

\begin{abstract}
The aim of this study was to determine the energy and protein requirements of crossbred Holstein $\mathrm{x}$ Zebu steers fed with or without the supplementation of dicalcium phosphate in the diet. Thirty-two steers with an average initial body weight of $377.5 \pm 49.4 \mathrm{~kg}$ were used, of which four were initially slaughtered to estimate the empty body weight (EBW) of the animals. Twenty-four steers were fed ad libitum and were distributed in a completely randomized design with two levels of concentrate (30 and $60 \%$ ), and diets with or without dicalcium phosphate and four steers were fed at maintenance level, so that the body weight gain was equal to zero. After 84 days the animals were slaughtered. The animal tissues were sampled, and composted by two samples, denominated by "carcass" (bone, muscle and fat) and "non-carcass" (head, limbs, blood, hide, organs and viscera) for determination of the body composition. The net energy requirements (NEm) and metabolizable energy for maintenance (MEm) were obtained while relating heat production (HP) and metabolizable energy intake (MEI); meanwhile, the net energy requirements for gain $(\mathrm{NEg})$ and the net protein requirements for gain $(\mathrm{NPg})$ were obtained as a function of empty body weight (EBW), empty body gain (EBG) and retained energy (RE) in EBW. The daily net and metabolizable energy requirements for maintenance were 76.90 and $119.36 \mathrm{kcal} / \mathrm{EBW}^{0.75}$, respectively. The net energy requirements for gain can be obtained by the following equation: $\mathrm{NEg}=$ $0.0568_{ \pm 0.0025} \times \mathrm{EBW}^{0.75} \times \mathrm{EBG}^{1.095}$. The efficiencies of use of metabolizable energy for maintenance and gain are 64.4 and $29.68 \%$, respectively. The metabolizable protein requirements for maintenance are $4.14 \mathrm{~g} / \mathrm{BW}^{0.75}$. The net protein requirements for gain can be obtained through the following equation: $\mathrm{NPg}=236.36_{ \pm 30.06} \times \mathrm{EBG}-19.84_{ \pm 6.14} \times \mathrm{RE}$. We recommend the use of the equations obtained in this experiment to calculate the energy and protein requirements of crossbred Holstein x Zebu steers.
\end{abstract}

Key words: Comparative slaughter. Efficiency. Growth. Maintenance.

\footnotetext{
${ }^{1}$ Discentes de Doutorado, Departamento de Zootecnia, Universidade Federal de Viçosa, UFV, Viçosa, MG, Brasil. E-mail: diego. zanetti@ufv.br; miguelreges@gmail.com

2 Profs., Dept ${ }^{\circ}$ de Zootecnia, UFV, Viçosa, MG, Brasil. E-mail: scvfilho@ufv.br; detmann@ufv.br; mpaulino@ufv.br

${ }^{3}$ Discentes de Mestrado, Departamento de Zootecnia, UFV, Viçosa, MG, Brasil. E-mail: marcos.pacheco@ufv.br; leticia.godoi@ ufv.br; breno.castro@ufv.br

${ }^{4}$ Prof $^{\mathrm{a}}$, Departamento de Zootecnia, Universidade Federal da Bahia, UFBA, Salvador, BA, Brasil. E-mail: stefanie_zootecnia@ hotmail.com

${ }^{5}$ Pós-doutoranda, Departamento de Zootecnia, UFBA, Salvador, BA, Brasil. E-mail: laysmariz@yahoo.com.br

* Author for correspondence
} 


\section{Resumo}

Objetivou-se determinar as exigências nutricionais de energia e proteína para bovinos castrados mestiços Holandês x Zebu alimentados com ou sem suplementação inorgânica de cálcio e fósforo na dieta. Foram utilizados 32 animais mestiços Holandês $\times$ Zebu, machos, castrados, com peso corporal (BW) médio inicial de $377,5 \pm 49,4 \mathrm{~kg}$, dos quais quatro foram abatidos inicialmente para estimar o peso de corpo vazio (EBW) dos demais, 24 alimentados ad libitum distribuídos em delineamento inteiramente casualizado com dois níveis de concentrado (30 e 60\%) e dietas contendo ou não fosfato bicálcico; e quatro alimentados ao nível de mantença, isto é, para que o ganho de peso corporal fosse igual a zero. Após 84 dias os animais foram abatidos. Para determinação da composição corporal dos animais, foram constituídas duas amostras por animal, denominadas "carcaça" (óssos, musculo e gordura) e "não carcaça" (cabeça, membros, sangue, couro, orgãos e visceras). As exigências de energia líquida (NEm) e metabolizável para mantença (MEm) foram obtidas relacionando a produção de calor (HP) e o consumo de energia metabolizável (MEI), enquanto as exigências de energia líquidas para ganho de peso (NEg) e as exigências líquidas de proteína para ganho (NPg) foram obtidas em função do EBW, do ganho de peso de corpo vazio (EBG), e da energia retida (RE) no EBW. As exigências diárias de energia líquida e metabolizável para mantença de bovinos mestiços Holandês $\times$ Zebu castrados foram de 76,90 e $119,36 \mathrm{kcal} / \mathrm{EBW}^{0,75}$, respectivamente. As exigências de energia líquida para ganho podem ser obtidas pela equação: $\mathrm{NEg}=0,0568_{ \pm 0,0025} \times \mathrm{EBW}^{0,75} \times \mathrm{EBG}^{1,095}$. As eficiências de uso da energia metabolizável para mantença e para ganho foram de 64,4 e 29,68\%, respectivamente. As exigências de proteína metabolizável para mantença foram de $4,14 \mathrm{~g} / \mathrm{BW}^{0,75}$. As exigências líquidas de proteína para ganho de peso podem ser obtidas através da equação $\mathrm{NPg}=236,36_{ \pm 30,06} \times \mathrm{EBG}-19,84_{ \pm 6,14} \times \mathrm{RE}$. Recomenda-se o uso das equações obtidas nesse experimento para cálculo das exigências nutricionais de energia e proteína para novilhos cruzados Holandês $\times$ Zebu castrados.

Palavras-chave: Abate comparativo. Crescimento. Eficiência. Mantença.

\section{Introduction}

For a long time, the balance of diets for cattle in Brazil used the nutritional requirements that are described by foreign systems due to the lack of data under national conditions. It was only in 2006 that the first version of Brazilian tables showing the nutrient requirements of Zebu beef cattle, named the BR-CORTE system, was actualized by Valadares Filho et al. (2006, 2010).

However, this database needs to be expanded with information about crossbred Holstein $\mathrm{x}$ Zebu animals, which make a significant contribution to the national herd due to the importance of these animals in the national milk production. Usually, the resulting steers of these crosses are finished as beef cattle (MADALENA et al., 1996). The lack of data regarding the crossbred Holstein $\mathrm{x}$ Zebu cattle in the BR-CORTE (VALADARES FILHO et al., 2010) justifies the inclusion of a specific chapter dealing with the nutritional requirements of these animals in the next edition of the BRCORTE, and thus an increase in the database is necessary. In addition, Prados et al. (2015) demonstrated that calcium $(\mathrm{Ca})$ and phosphorus $(\mathrm{P})$ supplementation is not necessary for this animal category in the finishing phase, since performance was not impaired. As the absence of $\mathrm{Ca}$ and $\mathrm{P}$ supplementation is applicable at farm level, it was included in the experiment.

Besides the nutritional requirements, an evaluation of the efficiency of the use of energy and protein for maintenance and body tissue deposition is essential; dealing with that efficiency also varies due to factors such as feed condition, the age of the animals and body weight gain composition (ROTTA et al., 2013). Therefore, the objective was to estimate the energy and protein requirements for crossbred Holstein x Zebu steers. 


\section{Material and Methods}

The experiment was conducted in the Experimental Feedlot of the Animal Science Department of the Universidade Federal de Viçosa, Viçosa, MG, Brazil following the recommendations of the Ethics Committee for Animal Use (CEUA/DZO/UFV Process number 77/2013).

\section{Animals}

Thirty-two crossbred $1 / 2$ Holstein $x$ Zebu steers with an average initial body weight of $377.5 \pm$ $49.4 \mathrm{~kg}, 18$ months old, were utilized. After 21 days of adaptation to local, the animals were randomly divided into three groups: baseline $(n=4)$, maintenance $(n=4)$ and performance $(n=24)$.

\section{Treatments and experimental design}

Initially, four steers were randomly selected and slaughtered. Before slaughter, these steers were subjected to fasting from feed for 16 hours, although water was available. These steers were utilized as the baseline group in order to estimate the initial EBW of the other animals. The steers from the maintenance group were fed $11 \mathrm{~g} \mathrm{DM} / \mathrm{kg} \mathrm{BW}$, as described in literature (COSTA E SILVA et al., 2012; MARCONDES et al., 2011). The performance animals were fed ad libitum. All steers were housed in individual pens provided with concrete feeders and drinkers, for 84 days. The experiment was conducted as a completely randomized design in a $2 \times 2$ factorial scheme with two levels of concentrate (30 and $60 \%$ ), with diets containing or lacking dicalcium phosphate. The total mixed ration that was provided was divided into portions twice a day at $8 \mathrm{~h} 00$ and $16 \mathrm{~h} 00$.

The diets were isonitrogenous with $12 \% \mathrm{CP}$ and were formulated according to the BR-CORTE 2010 (VALADARES FILHO et al., 2010) for an average daily gain of $1.2 \mathrm{~kg}$ when fed ad libitum. Fresh sugarcane was utilized as roughage and was corrected for $12 \% \mathrm{CP}$ on a DM basis with a urea and ammonium sulfate mixture in a proportion of $9: 1$. The concentrate was included in a proportion of 30 or $60 \%$ on a DM basis. The proportions of concentrate ingredients in the diets and its composition are shown in Table 1.

The feedstuffs were provided in individual feeders, sampled, and the intake was adjusted daily for maintain refusals around $5 \%$ of the feed offered in the previous day. Similarly, the refusals were sampled daily. These samples were grouped proportionally each week, dried in a forced-ventilation oven at $55{ }^{\circ} \mathrm{C}$, ground in a knife mill using a $1 \mathrm{~mm}$ screen and then packed under hermetic conditions prior to their laboratory analyses.

For evaluation of the digestibility of the diets, fecal and urine collection was conducted during weeks 4 and 9 of the experiment over $72 \mathrm{~h}$. Twentyfour $\mathrm{h}$ fecal and urine output was determined for all steers over a $72 \mathrm{~h}$ period. Feces were collected each day (over a $24 \mathrm{~h}$ period), weighed, thoroughly mixed and sampled daily. The feces were packed in aluminum trays, dried in a forced-air drying oven $\left(55^{\circ} \mathrm{C}\right)$ and ground through a $1 \mathrm{~mm}$ screen using a knife mill. For each animal, a composite sample was gathered for each collection period based on the dry weight of each day of collection for further laboratory analyses. 
Table 1. Proportions of ingredients and chemical composition of the experimental diets.

\begin{tabular}{|c|c|c|c|c|}
\hline \multirow{2}{*}{ Parameter } & \multicolumn{2}{|c|}{$60 \%$ Concentrate } & \multicolumn{2}{|c|}{$30 \%$ Concentrate } \\
\hline & $\mathrm{Wi} \mathrm{DP}^{1}$ & $\mathrm{WO} \mathrm{DP}^{2}$ & Wi DP & WO DP \\
\hline & \multicolumn{4}{|c|}{ Proportions (\%) } \\
\hline Sugarcane & 39.77 & 39.77 & 68.5 & 68.5 \\
\hline Urea/ammonium sulfate & 1.5 & 1.5 & 2.5 & 2.5 \\
\hline Salt & 0.4 & 0.4 & 0.2 & 0.2 \\
\hline Soybean meal & 2.6 & 2.6 & 1.1 & 1.1 \\
\hline Sodium bicarbonate & 0.5 & 0.5 & 0.3 & 0.3 \\
\hline Magnesium oxide & 0.3 & 0.3 & 0.1 & 0.1 \\
\hline Ground corn & 27.1 & 27.1 & 13.3 & 13.3 \\
\hline Soybean hulls & 27.7 & 27.7 & 13.67 & 13.67 \\
\hline Mineral mix & 0.03 & 0.03 & 0.03 & 0.03 \\
\hline Dicalcium phosphate & 0.1 & - & 0.3 & - \\
\hline Sand & - & 0.1 & - & 0.3 \\
\hline \multirow[t]{2}{*}{ Total } & 100.0 & 100.0 & 100.0 & 100.0 \\
\hline & \multicolumn{4}{|c|}{ Chemical composition } \\
\hline Dry matter & 63.91 & 63.91 & 46.37 & 46.37 \\
\hline Organic matter (\% DM) & 95.41 & 95.41 & 95.59 & 95.59 \\
\hline Ether extract (\% DM) & 1.79 & 1.79 & 1.66 & 1.66 \\
\hline apNDF (\% DM) & 42.08 & 42.08 & 46.48 & 46.48 \\
\hline Crude protein $(\% \mathrm{DM})$ & 11.76 & 11.76 & 11.82 & 11.82 \\
\hline Nonfiber carbohydrates (\% DM) & 42.18 & 42.18 & 39.63 & 39.63 \\
\hline Calcium (\% DM) & 0.40 & 0.37 & 0.46 & 0.38 \\
\hline Phosphorus (\% DM) & 0.16 & 0.14 & 0.15 & 0.10 \\
\hline
\end{tabular}

Wi DP, with dicalcium phosphate; WO DP, without dicalcium phosphate; apNDF, neutral detergent fiber corrected for protein and ash.

\section{Energy intake}

Subsamples of feedstuffs and feces were analyzed for dry matter (DM; method 934.01), ash (method 930.05), total nitrogen (N, method 981.10) and ether extract (EE, method 945.16), according to the AOAC (2012) protocols. The crude protein (CP) content was obtained by multiplying 6.25 by the total nitrogen content. Neutral detergent fiber (NDF) content was obtained according to Mertens et al. (2002) without the addition of sodium sulfite and with the addition of thermostable alfa-amylase. The NDF content was corrected for protein and ash for all samples (LICITRA et al., 1996). The nonfiber carbohydrates (NFC) were calculated according to the method described by Detmann and Valadares
Filho (2010), using the equation: $\mathrm{NFC}=\mathrm{OM}$ CP - apNDF - EE. The total digestible nutrients (TDN) contents of the diets were estimated using the following equation: $\mathrm{TDN}=\mathrm{dCP}+2.25 * \mathrm{dEE}+$ $\mathrm{dNDF}+\mathrm{dNFC}$ (NRC, 2001). The digestible energy (DE) was obtained from the digestible nutrients multiplied by their respective energy values, while the metabolizable energy concentration (ME) was calculated as DE x 0.82 as described by the NRC (2000). Although this coefficient $(82 \%)$ originated from Bos taurus and temperate conditions, Coelho da Silva and Leão (1979) recommended the adoption of this value in Brazilian conditions. Gionbelli (2013) found a similar coefficient $(80.24 \%)$ for the transformation of DE into ME in Nellore cows. 


\section{Metabolizable protein intake}

During the two total fecal collections, spot samples of urine were collected four hours after the morning feeding, which were then analyzed for the concentrations of creatinine, uric acid and allantoin. The analyses of creatinine and uric acid were performed in an automatic biochemical analyzer (Mindray, model BS200E), while the analysis of allantoin was performed as described by Chen and Gomes (1992).

The daily urinary volume was estimated by dividing the daily creatinine excretion (CE) by its concentration in the samples of urine. The CE (g/d) was estimated using the following equation described by Costa e Silva et al. (2012): CE = $0.0345 \times \mathrm{BW}^{0.9491}$, where BW was expressed in $\mathrm{kg}$.

The total excretion of purine derivatives (PD) was calculated by the sum of the amounts of allantoin and uric acid excreted in the urine, expressed in $\mathrm{mmol} / \mathrm{d}$ and obtained from the product of their concentration in the urine and the estimated urinary volume.

The absorbed purines (AP, mmol/d) were calculated from the PD excretion (PD, $\mathrm{mmol} / \mathrm{d}$ ) by using the following equation: $A P=\frac{P D-0.3 \times B W^{0.75}}{0.80}$, where 0.80 is the recovery of absorbed purines as $\mathrm{PD}$ and $0.30 \mathrm{BW}^{0.75}$ is the endogenous purine excretion (BARBOSA et al., 2011).

The ruminal synthesis of nitrogen compounds (SCN, g N/d) was calculated as a function of AP (mmol/d) by using the following equation (BARBOSA et al., 2011): $S C N=\frac{70 \times A P}{0.93 \times 0.137 \times 1000}$, where 70 is the $\mathrm{N}$ content from purines $(\mathrm{mgN} / \mathrm{mmol})$, 0.137 is the purine $\mathrm{N}$ :total $\mathrm{N}$ ratio in bacteria and 0.93 is the true digestibility of microbial purines. The microbial efficiency (g MCP/kg TDN) was obtained by dividing the microbial crude protein production $(\mathrm{MCP}=6.25 * \mathrm{SCN})$ by TDN intake.

The metabolizable protein intake was estimated from the sum of true digestible microbial protein (DMCP) and digestible rumen nondegradable protein (DRUP). The DMCP was calculated from the TDN intake, where $80 \%$ was considered to be the true fraction and $80 \%$ was the digestibility recommended by the NRC (2001). The RUP intake was calculated as follows: $R U P=\frac{C P-D M C P}{0.8}$.

\section{Comparative slaughter}

The animals were submitted to fasting from solids for 16 hours. The slaughter was performed by stunning via brain concussion, followed by bleeding by cutting the jugular vein. The digestive tract (rumen-reticulum, omasum, abomasum, and small and large intestines) of each animal was emptied, washed and weighed. This weight was summed with the weights of the heart, lungs, liver, spleen, kidneys, fat contained in the regions of the kidney, pelvis and heart, diaphragm, tail, reproductive tract, trachea, esophagus, head, hide, feet, blood and carcass for the determination of the EBW.

The rumen-reticulum, omasum, abomasum, small intestine, large intestine, liver, heart, kidneys, lungs, tongue, spleen, diaphragm, esophagus, trachea, reproductive tract and fat contained in the regions of the kidney, pelvic and heart were ground in an industrial cutter for 20 minutes to create a homogenous sample of organs and viscera.

The hide from the feet and head of each animal was removed and the residual was ground in a bone grinder to make a composite sample of the paws and head. The hide was manually cut and sampled. Samples of blood were collected immediately after the slaughter, and just like the samples of organs and viscera, the head, paws and hide were packed in aluminum trays and lyophilized.

After harvest, the carcass of each animal was divided into two halves, which were weighed and then cooled in a cold chamber at $4{ }^{\circ} \mathrm{C}$ for 18 hours. After this time, the half-carcasses were removed from the cold chamber to be weighed and for the complete dissection of the left half-carcass. Bone, 
meat and fat were ground, sampled and lyophilized. All samples were ground through a $1 \mathrm{~mm}$ screen using a knife mill (model TE 650/1, Tecnal, Piracicaba - SP, Brazil).

\section{Body composition}

Two samples were assembled, carcass and noncarcass, with the carcass sample consisting of lyophilized samples of bone, meat and fat that were grouped proportionally based on air-dry weight. The samples of the noncarcass components consisted of lyophilized samples of blood, head and paws, organs and viscera, and hide, which were also grouped proportionally based on their weights in the body of the animal.

The ratio between EBW and shrunk body weight (SBW) of the animals in the experiment was calculated based on the conversion of shrunk body weight obtained after solids fasting for $16 \mathrm{~h}$ to EBW. For the conversion from average daily gain to empty body gain, the ratio between these variables was calculated.

The body content of fat and protein was determined in the samples of the carcass and noncarcass components. The body energy was obtained based on the sum of body contents of protein and fat and their respective caloric equivalents according to the equation of the ARC (1980): $\mathrm{EC}=5.6405 \times \mathrm{BP}+9.3929 \times \mathrm{BF}$, where $\mathrm{EC}=$ energy content $(\mathrm{Mcal}), \mathrm{BP}=$ body protein $(\mathrm{kg})$ and $\mathrm{BF}=$ body fat $(\mathrm{kg})$.

The energy and protein contents in the body as a function of EBW of the animals were estimated using equations relating the body content of energy and protein of the reference and performance animals, according to the following model: $\mathrm{Ci}=\alpha$ $\times \mathrm{EBW}^{\beta}$, where $\mathrm{Ci}=$ constituent " $\mathrm{i}$ " of the animal's body, which can be energy (Mcal) or protein $(\mathrm{kg})$, $\mathrm{EBW}=$ empty body weight, and " $\alpha$ " and " $\beta$ " = regression parameters.

\section{Calculations of energy and protein requirements}

The heat production was calculated as the difference between MEI and RE. The net energy requirements for maintenance (NEm, Mcal/ $\left.\mathrm{EBW}^{0.75}\right)$ were calculated from the intercept $(\beta 0)$ of the regression between HP and MEI. The utilized model was the following: $\log \mathrm{HP}=\beta 0+\beta 1 \times \mathrm{MEI}$, where $\mathrm{HP}=$ heat production $\left(\mathrm{Mcal} / \mathrm{EBW}^{0.75}\right)$, MEI $=$ metabolizable energy intake $\left(\mathrm{Mcal} / \mathrm{EBW}^{0.75}\right)$, and $\beta 0$ and $\beta 1$ are the regression parameters.

The metabolizable energy requirements for maintenance (MEm, Mcal/EBW ${ }^{0.75}$ ) were obtained by the iterative method, where MEm was considered to be the value of MEI at the moment when the MEI was equal to HP. The efficiency of metabolizable energy use for maintenance $(\mathrm{km})$ was calculated as the ratio between the net and metabolizable energy requirements for maintenance.

The retained energy was calculated as the difference between final and initial body composition. A regression equation between retained energy (RE) and EBG for a determined metabolic EBW $\left(\mathrm{kg}^{0.75}\right)$ was developed for the calculation of the requirements of any range of weight by using the following model: $\mathrm{RE}=\alpha \times$ $\mathrm{EBW}^{0.75} \times \mathrm{EBG}^{\beta}$, where $\mathrm{RE}=$ retained energy $(\mathrm{Mcal} /$ $\left.\mathrm{EBW}^{0.75}\right), \mathrm{EBG}=$ empty body gain $(\mathrm{kg} / \mathrm{d})$, and " $\alpha$ " and " $\beta$ " = regression coefficients. To estimate the ME requirements for gain, it is necessary to know the efficiency of use of metabolizable energy $(\mathrm{kg})$. This efficiency is considered to be the inclination coefficient of the equation, which was obtained based on the RE in the body of the animals and ME intake.

The metabolizable protein requirements for maintenance were calculated according to BRCORTE (VALADARES FILHO et al., 2010), where the metabolizable protein intake (MPI) was expressed as a function of the EBG for the performance and maintenance steers: $\mathrm{MPI}=\beta 0$ $+\beta 1 \times$ EBG. The division of the intercept of this 
regression by the metabolic weight of the animals results in the metabolizable protein requirements for maintenance (MPm).

The net protein requirements for gain $(\mathrm{NPg})$ were calculated according to Marcondes et al. (2010): $\mathrm{Pg}=\beta 0 \times \mathrm{EBG}+\beta 1 \times \mathrm{RE}$, where $\mathrm{EBG}$ and $\mathrm{RE}$ are expressed in $\mathrm{kg} / \mathrm{d}$ and $\mathrm{Mcal} / \mathrm{d}$, respectively. The metabolizable protein requirements for gain (MPg) were calculated by dividing the NPg by the efficiency of the use of metabolizable protein for gain (k). This efficiency $k$ was considered to be the regression coefficient obtained between the retained protein and the metabolizable protein intake.

\section{Statistical analyses}

To estimate the requirements different levels of intake nutrients are necessary, since linear and nonlinear regression are the main tool for the determination of nutritional requirements. Therefore, the dietary treatments were not considered in the statistical analysis. Factorial design was not used as a way to analyze data for comparative differences among dietary levels, but to collect source data to generate the equations. The linear models were built using the PROC REG of SAS (SAS Institute Inc., Cary, NC), while for nonlinear models the PROC NLIN of SAS was utilized. For all tests, the critical level of 0.05 probability was utilized for the type-I error.

\section{Results and Discussion}

\section{Empty body weight}

The linear regression between BW and SBW did not present a significant intercept, as $\mathrm{SBW}=0.981 \times$ $\mathrm{BW}, \mathrm{r}^{2}=0.99$. The linear regression between SBW and EBW did not present a significant intercept either, as $\mathrm{EBW}=0.861 \times \mathrm{SBW}, \mathrm{r}^{2}=0.93$.

This ratio was lower than those described by the BR-CORTE (VALADARES FILHO et al., 2010) at 0.895 and the NRC (2000) at 0.891. However, the
NRC reports that these values can vary between 0.85 and 0.95. Due to the presence of Holstein breed, the observed DM intake was greater than that predicted by these systems because of a greater fill capacity, which explains the lowest value of 0.861 . In a study using crossbred Zebu x Holstein, Amaral (2012) also found a ratio $(0.878)$ that was lower than those recommended by the referring councils.

The ratio between average daily gain (ADG) and EBG was obtained using the following equation: $\mathrm{EBG}=0.879 \times \mathrm{ADG}, \mathrm{r}^{2}=0.99$. Despite the fact that the expected value for this ratio was lower than 1 , the value of 0.879 is lower than that reported by the BR-CORTE, which adopts the value of 0.966 for crossbred animals in a feedlot. The justification for this lower value is that the ratio between the EBW and SBW of crossbred Holstein $\mathrm{x}$ Zebu animals is lower than those found for other beef breeds such as Nellore. It is worth noting that large animals presented a lower proportion of gut tract in relation to body weight, as this can justify the lower value that was found. The relation obtained for the gut tract content was $(\mathrm{g} / \mathrm{kg} \mathrm{SBW})=2560.2 \mathrm{x} \mathrm{SBW}^{-0.4788}$. The value of exponent $(\beta 1)$ was similar to that found by Costa e Silva et al. (2012) for Nellore (-0.467); however, the value of slope coefficient $(\beta 0)$ that was obtained for Nellore was 1308.2 versus 2560.2 for crossbred Holstein x Zebu animals in this study.

\section{Energy requirements for maintenance}

The equation that was obtained when heat production was related to metabolizable energy intake was as follows: $\log \mathrm{HP}=1.8859+0.0016 \mathrm{MEI}$, where $\mathrm{HP}$ and MEI are expressed in Mcal/EBW $\mathrm{EW}^{0.75} / \mathrm{d}$. Thus, the value for the net energy requirements for maintenance of crossbred animals was $76.90 \mathrm{Kcal} /$ $\mathrm{EBW}^{0.75}$, as estimated by the antilogarithm of the intercept of the equation above.

Some studies (AMARAL, 2012; PRADOS, 2012) have found greater NEm requirements for crossbred Holstein $\mathrm{x}$ Zebu animals. However, the value that we found is similar to those recognized by 
the BR-CORTE and the NRC (2000) for crossbred animals, which were 74.2 and $77 \mathrm{Kcal} / \mathrm{EBW}^{0.75}$, respectively, probably because of the little influence of the Holstein breed on this value. With regard to $\mathrm{MEm}$, a value of $119.37 \mathrm{Kcal} / \mathrm{EBW}^{0.75}$ was found, at the moment where the MEI is equal to HP.

The efficiency of the use of ME for maintenance $(\mathrm{km})$ was obtained by dividing NEm by MEm (76.9/119.37), which yielded a value of 0.644. This value is similar to that observed by the BR-CORTE of 0.64 for Bos indicus steers.

\section{Energy requirements for gain}

The equation obtained based on the energy body content (EC) in Mcal and the empty body weight (EBW, kg) was as follows: $\mathrm{EC}=0.1014 \times$ $\mathrm{EBW}^{1.5462}$; it can be seen that there is an increased energy content in the body of the animal when there is an increased EBW due to greater fat deposition in heavier animals. To obtain the NEg for any EBW and EBG, the following equation was adjusted: $\mathrm{NEg}=0.0568 \times \mathrm{EBW}^{0.75} \times \mathrm{EBG}^{1.095}$. The slope coefficient found for crossbred steers in this experiment was lower than that reported by the BR-CORTE of 0.064 for steers, but this may be justified by the lower fat deposition in crossbred Holstein x Zebu animals. The efficiency of use of metabolizable energy $(\mathrm{kg})$ is considered to be the inclination coefficient of the equation, which was obtained based on the retained energy in the body of the animals (RE) and ME intake: RE (Mcal/ EBW $)=-0.0335+0.297 \times$ MEI $\left(r^{2}=0.82\right)$ A value of 0.297 was found, which is lower than those obtained by Amaral (2012) and Rotta et al. (2013) for crossbred Holstein x Zebu bulls of 0.36 and 0.46 , respectively.

Subcutaneous fat thickness (SFT) is an indicator of the quantity of fat in a carcass. In this study, the SFT observed was $3.64 \mathrm{~mm}$, a value close to the lower limit required by Brazilian slaughterhouses (COSTA et al., 2002). This reduced fat deposition could be related to the lower values found, to $\mathrm{kg}$ and to the slope coefficient in NEg, since the energetic content in fats is approximately 1.66 times higher than in protein $(9.3929$ versus $5.6405 \mathrm{Mcal} / \mathrm{kg}$ ). In addition, a greater efficiency of nutrient utilization coefficients is described for bulls than for castrated animals. However, these coefficients are not described for Hostein x Zebu steers in the consulted literature.

\section{Protein requirements for maintenance}

The observed microbial efficiency was 115.0 $\mathrm{g} \mathrm{MCP} / \mathrm{kg}$ TDN. Despite the different levels of concentrate offered among treatments, a difference in this parameter was not observed among treatments. The lowest microbial protein synthesis occurred; therefore, the lowest TDN intake was observed. The BR-CORTE adopts a value of 120 $\mathrm{g} / \mathrm{kg}$ TDN for microbial efficiency, while the NRC (2000) recognizes a value of $130 \mathrm{~g} / \mathrm{kg}$ TDN. To estimate the metabolizable protein intake (MPI) of the animals, the value that was found in this experiment was utilized. To relate the MP intake and $\mathrm{EBG}$, the following equation was obtained: MPI $=368.34+598.58 \times$ EBG, $r^{2}=0.86$. Dividing the intercept by the average $\mathrm{SBW}^{0.75}$ (89.0), the metabolizable protein requirement for maintenance (MPm) obtained was $4.14 \mathrm{~g} / \mathrm{BW}^{0.75}$. This value is a little greater than the values recognized by both the NRC (2000) and the BR-CORTE, which were 3.8 and $4.0 \mathrm{~g} / \mathrm{BW}^{0.75}$, respectively.

\section{Protein requirements for gain}

The net protein requirements for gain $(\mathrm{NPg})$ were estimated from the equation: $\mathrm{NPg}=236.36 \times \mathrm{EBG}$ - $19.84 \times \mathrm{RE}$, where EBG and RE are expressed in $\mathrm{kg} / \mathrm{d}$ and $\mathrm{Mcal} / \mathrm{d}$, respectively.

Through the following equation adjusted for retained protein (RP) and metabolizable protein intake (MPI), the efficiency of use of metabolizable protein for gain $(\mathrm{k})$ was $26.72 \%$ : $\mathrm{RP}=-1.2962+$ 
$0.2672 \times$ MPI, $\mathrm{r}^{2}=0.79$; this value was lower than that reported by other authors (AMARAL, 2012; COSTA E SILVA, 2011; GIONBELLI, 2010; PRADOS, 2012), by the BR-CORTE, which recommends a value of 0.469 , and by the NRC (2000), which recognized a value of 0.492 . For Holstein animals, the NRC (2001) recognized an efficiency of $28.9 \%$ for animals above $487 \mathrm{~kg}$, and for animals of $403 \mathrm{~kg}$ the estimated value was 0.375 , which justifies the reduced efficiency that was observed in this experiment.
The parameters that were obtained in this experiment for NPg were greater than those predicted by the BR-CORTE for crossbred steers. However, this value can be considered normal due to the low inclination coefficient, which can increase the metabolizable protein requirements for gain.

\section{Summary of the equations and generated values}

A summary of the equations and values generated in this experiment is given in Table 2 .

Table 2. Summary of the equations and generated values.

\begin{tabular}{ccc}
\hline Item & Equation & Unit \\
\hline SBW & $\mathrm{SBW}=0.981 \times \mathrm{BW}$ & $\mathrm{Kg}$ \\
$\mathrm{EBW}$ & $\mathrm{EBW}=0.861 \times \mathrm{SBW}$ & $\mathrm{Kg}$ \\
$\mathrm{EBG}$ & $\mathrm{EBG}=0.8791 \times \mathrm{ADG}$ & $\mathrm{Kg} / \mathrm{day}$ \\
$\mathrm{Nem}$ & 76.90 & $\mathrm{Kcal} / \mathrm{EBW}^{0.75} /$ day \\
$\mathrm{Mem}$ & 119.37 & $\mathrm{Kcal} / \mathrm{EBW}^{0.75} /$ day \\
$\mathrm{Km}$ & 64.4 & $\%$ \\
$\mathrm{Neg}$ & $\mathrm{NEg}=0.0568_{ \pm 0.0025} \times \mathrm{EBW}^{0.75} \times \mathrm{EBG}^{1.095}$ & $\mathrm{Mcal} /$ day \\
$\mathrm{kg}$ & 29.68 & $\%$ \\
$\mathrm{Meg}$ & $\mathrm{NEg} / \mathrm{kg}$ & $\mathrm{Mcal} / \mathrm{day}$ \\
$\mathrm{ME}$ & $\mathrm{MEm}+\mathrm{Meg}$ & $\mathrm{Mcal} / \mathrm{day}$ \\
$\mathrm{MPm}$ & $\mathrm{MPm}=4.14 \times \mathrm{EBW}^{0.75}$ & $\mathrm{~g} /$ day \\
$\mathrm{NPg}$ & $\mathrm{g} /$ day \\
$K$ & $\mathrm{NPg}=236.36_{ \pm 30.06} \times \mathrm{EBG}-19.84_{ \pm 6.14} \times \mathrm{RE}$ & $\%$ \\
\hline
\end{tabular}

EBW, empty body weight; SBW, shrunk body weight; EBG, empty body gain; ADG, average daily gain; NEm, net energy requirements for maintenance; MEm, metabolizable energy for maintenance; km, efficiency of the use of metabolizable energy for maintenance ; NEg, net energy requirements for gain; $\mathrm{kg}$, efficiency of the use of metabolizable energy; MEg, metabolizable energy for gain; DE, digestible energy; TDN, total digestible nutrients; MPm, metabolizable protein requirements for maintenance; NPg, net protein requirements for gain; $\mathrm{k}$, efficiency of the use of metabolizable protein for gain.

\section{Conclusions}

The net and metabolizable energy requirements for the maintenance of crossbred Zebu $\times$ Holstein steers are 76.90 and $119.37 \mathrm{kcal} / \mathrm{EBW}^{0.75} / \mathrm{d}$, respectively. The net energy requirements for gain can be obtained by using the following equation: $\mathrm{NEg}=0.0568_{ \pm 0.0025} \times \mathrm{EBW}^{0.75} \times \mathrm{EBG}^{1.095}$.

The efficiencies of the use of metabolizable energy for maintenance and for gain in crossbred Zebu $\times$ Holstein steers are 0.644 and 0.2968, respectively.

The metabolizable protein requirements for maintenance are $4.14 \mathrm{~g} / \mathrm{BW}^{0.75}$, while the net protein requirements for gain can be obtained by using the following equation: $\mathrm{NPg}(\mathrm{g} /$ day $)=236.36_{ \pm 30.06} \times \mathrm{EBG}$ $-19.84_{ \pm 6.14} \times$ RE for crossbred Holstein $\times$ Zebu steers. 


\section{Acknowledgment}

The authors would like to thank the $\mathrm{CNPq}$ Conselho Nacional de Desenvolvimento Científico e Tecnológico (National Council for Scientific and Technological Development/Brazil) - for financing the research.

\section{References}

AGRICULTURAL RESEARCH COUNCIL - ARC. The nutrient requirements of ruminant livestock. London: The Gresham Press, 1980. 351 p.

AMARAL, P. M. Desempenho e exigências nutricionais de bovinos mestiços Holandês $x$ zebu alimentados com dietas contendo diferentes níveis de proteína. 2012. Dissertação (Mestrado em Zootecnia) - Universidade Federal de Viçosa, Viçosa, MG.

ASSOCIATION OF OFFICIAL ANALYTICAL CHEMISTS - AOAC. Official method of analysis. $17^{\text {th }}$ ed. Maryland: Association of Official Analytical Chemists, Inc., 2012. v. 1.

BARBOSA, A. M.; VALADARES, R. F. D.; VALADARES FILHO, S. D. C.; PINA, D. S.; DETMANN, E.; LEÃO, M. I. Endogenous fraction and urinary recovery of purine derivatives obtained by different methods in Nellore cattle. Journal of Animal Science, Champaign, v. 89, n. 2, p. 510-519, 2011.

CHEN, X. B.; GOMES, M. J. Estimation of microbial protein supply to sheep and cattle based on urinary excretion of purine derivatives: an overview of technical details (Occasional publication). International Feed Resources Unit. Bucksburn, Aberdeen: Rowelt Research Institute, 1992. $21 \mathrm{p}$.

COELHO DA SILVA, J. F.; LEÃO, M. I. Fundamentos de nutrição dos ruminantes. Piracicaba: Livroceres, $1979.380 \mathrm{p}$.

COSTA, E. C.; RESTLE, J.; VAZ, F. N.; ALVES FILHO, D. C.; BERNARDES, R. A. L. C.; KUSS, F. Características da carcaça de novilhos Red Angus superprecoces abatidos com diferentes pesos. Revista Brasileira de Zootecnia, Viçosa, MG, v. 31, n. 1, p. 119128, 2002.

COSTA E SILVA, L. F. Exigências nutricionais, validação de equações para a estimação da composição do corpo vazio e uso da creatinina para estimar a proporção de tecido muscular em bovinos Nelore. 2011. Dissertação (Mestrado em Zootecnia) - Universidade Federal de Viçosa, Viçosa, MG.
COSTA E SILVA, L. F.; VALADARES FILHO, S. D. C.; CHIZZOTTI, M. L.; ROTTA, P. P.; PRADOS, L. F.; VALADARES, R. F. D.; ZANETTI, D.; BRAGA, J. M. D. S. Creatinine excretion and relationship with body weight of Nellore cattle. Revista Brasileira de Zootecnia, Viçosa, MG, v. 41, n. 3, p. 807-810, 2012.

DETMANN, E.; VALADARES FILHO, S. C. On the estimation of non-fibrous carbohydrates in feeds and diets. Arquivo Brasileiro de Medicina Veterinária e Zootecnia, Belo Horizonte, v. 62, n. 4, p. 980-984, 2010.

GIONBELLI, M. P. Desempenho produtivo e exigências nutricionais de fêmeas Nelore em crescimento. 2010. Dissertação (Mestrado em Zootecnia) - Universidade Federal de Viçosa, Viçosa, MG.

Nutrient requirements and quantitative aspects of growth, development and digestion of pregnant and non-pregnant Nellore cows. 2013. Tese (Doutorado em Zootecnia) - Universidade Federal de Viçosa, Viçosa, MG.

LICITRA, G.; HERNANDES, T. M.; VAN SOEST, P. J. Standardizations of procedures for nitrogen fractionation of ruminant feeds. Animal Feed Science and Technology, Philadelphia, v. 57, n. 4, p. 347-358, 1996.

MADALENA, F. E.; LEMOS, A. M.; TEODORO, R. L.; PENNA, V. M. Desempenho comparativo de vacas mestiças Holandês-Guzerá de origem leiteira e não leiteira. In: REUNIÃO ANUAL DA SOCIEDADE BRASILEIRA DE ZOOTECNIA, 33., 1996, Fortaleza. Anais... Fortaleza: Sociedade Brasileira de Zootecnia, 1996. p. 3-4.

MARCONDES, M. I.; GIONBELLI, M. P.; VALADARES FILHO, S. C.; CHIZZOTTI, M. L.; PAULINO, M. F. Exigências nutricionais de proteína para bovinos de corte. In: VALADARES FILHO, S. de C.; MARCONDES, M. I.; CHIZZOTTI, M. L.; PAULINO, P. V. R. (Org.). Exigências nutricionais de zebuínos puros e cruzados BR-CORTE. 2. ed. Visconde do Rio Branco: Suprema Gráfica e Editora Ltda., 2010. v. 1, p. 113-134.

MARCONDES, M.; VALADARES FILHO, S. C.; OliVEIRA, I.; PAUlinO, M.; PAUlinO, P.; DETMANN, E.; COSTA E SILVA, L. F. Exigências de energia de animais Nelore puros e mestiços com as raças Angus e Simental. Revista Brasileira de Zootecnia, Viçosa, MG, v. 40, n. 4, p. 872-881, 2011.

MERTENS, D. R. Gravimetric determination of amylasetreated neutral detergent fibre in feeds with refluxing beakers or crucibles: collaborative study. Journal of AOAC International, Rockville, v. 85, n. 6, p. 1217-1240, 2002. 
NATIONAL RESEARCH COUNCIL - NRC. Nutrient requirements of beef cattle. $7^{\text {th }}$ ed. Washington: The National Academies Press, 2000. 242 p.

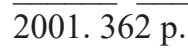
Washington: National Academy Press,

PRADOS, L. F. Desempenho e exigências nutricionais de bovinos alimentados com dietas contendo diferentes níveis de cálcio e fósforo. 2012. Dissertação (Mestrado em Zootecnia) - Universidade Federal de Viçosa, Viçosa, MG.

PRADOS, L. F.; VALADARES FILHO, S. C.; SANTOS, S. A.; ZANETTI, D.; NUNES, A. N.; COSTA, D. R.; MARIZ, L. D. S.; DETMANN, E.; AMARAL, P. M.; RODRIGUES, F. C.; VALADARES, R. F. D. Reducing calcium and phosphorus in crossbred beef cattle diets: impacts on productive performance during the growing and finishing phase. Animal Production Science, Melbourne, v. 55, n. 11, p. 1369-1374, 2015.
ROTTA, P. P.; VALADARES FILHO, S. C.; DETMANN, E.; COSTA, L. F.; VILLADIEGO, F. A. C.; BURGOS, E. M. G.; SILVA, F. A. S. Nutrient requirements of energy and protein for Holstein $\times$ Zebu bulls finished in feedlot. Semina: Ciências Agrárias, Londrina, v. 34, n. 5, p. 2523-2534, 2013.

VALADARES FILHO, S. C.; MARCONDES, M. I.; CHIZZOTTI, M. L.; PAULINO, P. V. R. Exigências nutricionais de zebuinos puros e cruzados - BR-CORTE. 2. ed. Viçosa, MG: UFV, Suprema Gráfica Ltda., 2010. $193 \mathrm{p}$.

VALADARES FILHO, S. C.; PAULINO, P. V. R.; MAGALHÃES, K. A. Exigências nutricionais de zebuínos e tabelas de composição de alimentos - BRCORTE. Viçosa, MG: UFV, Suprema Gráfica Ltda., 2006. $142 \mathrm{p}$. 
